\title{
Mediating punctuation in English Arabic translation
}

\author{
Jamal Alqinai \\ Kuwait University \\ jamalqinai@hotmail.com
}

\begin{abstract}
In this article we investigate some of the salient differences in punctuation between Arabic and English. Although both languages share many of the basic punctuation marks such as the period, the comma, and the question and exclamation marks, Arabic has its own method of punctuation which is not strictly governed by the same rules as in English. Even punctuation marks that were transferred from European languages through translation have been adapted to the writing conventions of Arabic. The comma, quotation marks and parentheses have been utilized with multiple and sometimes overlapping functions, but other marks like the apostrophe and the semicolon have rarely if ever been used in original Arabic texts. In some cases, English punctuational marks are either deleted or substituted by Arabic lexical insertions. Our study examines how meaning is realigned and structure reordered while translating between English and Arabic in order to retain the function of missing punctuation marks in the TT.
\end{abstract}

Keywords: punctuation, translation

\section{Introduction}

Punctuation is one of the paralinguistic graphological properties of text. Like suprasegmental features, punctuation marks help to read a text in a coherent way and understand its rhythm and tempo. Yet, until around the 9th century A.D, the earliest records of written scripts had no systematic punctuation and words were separated by haphazard spaces. Ancient Greek manuscripts separated units of text by horizontal lines which came to represent paragraph boundaries while the "comma," "colon," and "period" were invented in the 3rd century B.C. The hyphen was introduced around the 11th century to indicate that a given word was continued on the next line and the policy of indenting the beginning of paragraphs was standard by the 17th century (Robbins 1988:1). However, early punctuation was based on speech rather than on the logical structure of written sentences. After the invention of printing, grammarians developed a theory of punctuation related to written structure rather than speech.

The earliest reference to the visual effect of graphological translation and punctuational modes was initiated by Catford in 1965. In his book, A Linguistic Theory of Translation, he describes graphological translation as difficult because, "we have no systematic theory of 'general graphetics' from which to draw categories for the description of graphic substance" (Catford 1965: 62). Under 'graphetic categories' which he labels as ad hoc, he considers the rendition of various forms of vertical, horizontal, cursive caps and lower case characters with examples ranging from Russian Cyrillic, Greek, English, Arabic Burmese and Armenian (Catford 1965: 63-5). Graphologically, the boundary of a sentence can be defined as that which begins with a capital letter and ends with a full stop or some other mark of final punctuation like a question or exclamation mark (Catford 1965: 94). The problem is that some languages do not use conventional punctuation as a marker of sentence divisions and even in those languages that 
do, punctuation is not always a clear guide; its rules are prescribed as conventional 'good practice' and they vary from one language to another. In some texts, punctuation marks like the period and quotation marks are omitted altogether as in legal preambles, public signs, notices and newspaper headlines. On the other hand, it is difficult to rely on speech to extrapolate sentence demarcation points as spoken varieties and dialects vary in rhythm and intonation which do not often coincide with the occurrence of punctuation marks.

Punctuation marks help the reader in understanding the line of coherence that links phrases, sentences and paragraphs. It often marks discourse features such as intonational contours, pauses and emphasis. Nonetheless, variations in punctuation can be seen in members of the same language family as well as culturally-distinct languages. For instance, the quotation marks used to enclose direct quotation in English, are not used by the French, who use either a dash (--) at the opening of a quotation, or angle brackets $(<>)$ to surround it. Where English would use underlining or italics to indicate emphasis, quotation marks are sometimes used in other languages, like Spanish (Ibid) and heavy typeface is used in Chinese. Likewise, repeated letters as in 'no-o' denote emphasis in Russian but signal hesitation in English (Crystal 1988: 180). Such variations become even more evident in translating between languages of different families and cultures such as English and Arabic.

Ancient Arabic writing had no fixed system for representing punctuation marks or short vowels; the diacritical marks for distinguishing similar letters were added around the seventh century (Chejne 1969: 28, 157). Since Arabic was originally a spoken language that relied on audible intonational patterns, written representations of punctuation marks were not given primacy and, even today, they do not follow a strict rule-governed system as in English. In fact, early punctuation marks followed different conventions that were more related to speaking than to reading. As Arabic rhetoric is mainly concerned with speech, there was a need to use marks that indicate when the speaker should pause, link or give emphasis. Therefore, rather than being related to the logical structure of written sentences, early punctuation was based on the requirements of the art of oration. Later on, all forms of punctuation became standardized with printing as grammarians developed a theory of punctuation related to structure rather than sound. Nowadays, Arabic uses additional alternative means of punctuation such as diacritics and lexical insertions. Thus, for example, diacritics, which are superscript or subscript short vowel symbols $(\sim / \% / \dot{\circ})$ are placed above or below letters to indicate grammatical function as well as pronunciation and intonation. A final / \& / also called 'sukoon' [vowelless case] indicates a neutral uninflected allophone that stands for a pause or a full stop. Similarly, the Quran uses traditional symbols such as the superscript ${ }^{-}$to indicate a mandatory pause, ${ }^{\gamma}$ for a mandatory non-stop, $\underset{f}{\circ}$ to signal a run-on reading and for a pause. Verse endings are marked by a decorative symbol with an insert serial number $\bigcirc$ while the end of a section (called part) is marked by another symbol similar to $\&$ (The Noble Qur'an: 943-946).

Upon translating an Arabic text into English, one has to realign meaning and reorder structures in order to introduce missing punctuation marks. For instance, the full stop is not the only mark that signals the end of a sentence; a comma is more frequently opted for. Sometimes, a full stop is used at the end of every sentence. Alternatively, some Arab writers tend to write very long sentences, some of which could be a paragraph long with one full stop at the end and several commas and conjunctive devices in between (Othman 2004: 18). Some ST Punctuation marks are rendered by lexical equivalents in Arabic, a phenomenon that will not only result in altering the formal effect of the original but may also increase the total number of word count in the TT. In the following sections, the paper will investigate some salient divergences in 
punctuation marks between English and Arabic and how they reflect on the process of translating between the two languages.

\section{Space segmentation}

Spaces are used to identify maximal units of discourse such as paragraphs and separate units of grammar such as sentences, clauses, phrases and words. Indentation marks the first line of a new paragraph while extra space is entered between paragraphs to indicate a break in discourse. Generally speaking, Arabic writings separate paragraphs by spaces even though indentation is very rare in original Arabic writing. Most cases of indentation are reproductions of Western works translated into Arabic.

From a translation perspective, Hatim (1990:124-7) sets a distinction between structural and graphological paragraphing. He propounds that ST visual signals like spaces, indentation and transitional adverbials do not necessarily warrant a structural division of chunks of discourse into separate paragraphs in the TT and vice-versa. Orthographic division of paragraphs may be based on printing conventions or the 'eye appeal' factor rather than a structural or topical shift (Longacre 1979: 116). A case in point is the high frequency of discourse markers or 'superstructure' conjunctions in Arabic that determine the level of coherence without the need for visual space divisions. Discourse markers such as 'the following,' 'first,' 'second,' 'finally,' 'in conclusion,' 'as mentioned above,' abound in Arabic as signals for topical development and paragraph boundaries; they indicate explicitly the relationship between parts of a text. For example, the following excerpt is visually divided into two paragraphs whereas its Arabic ولهذا [therefore, so] with no effect on the coherence of topical progression.

Park then conducted a little survey. He asked Gary Gorton, a Yale professor who had helped build the model Cassano used to price the credit-default swaps. Gorton guessed the piles were no more than 10 percent subprime. He asked a risk analyst in London, who guessed 20 percent.

Cassano simply trusted the models, even when the models weren't designed for subprime in particular, or even really for mortgages. (Adapted from: Newsweek, 2.7.2009)

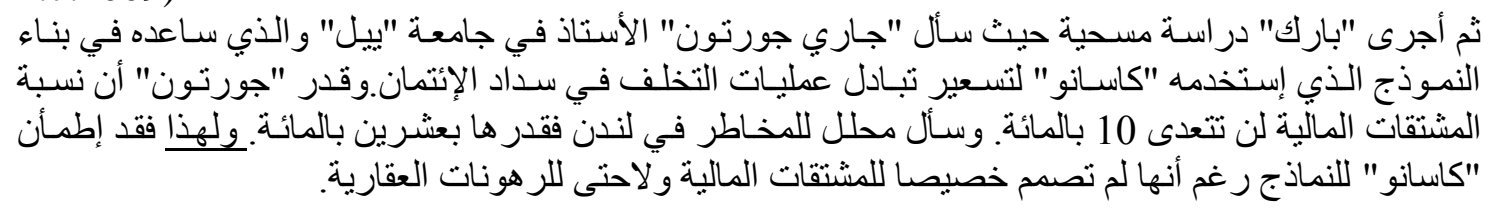

When back-translating the Arabic text into English, one should be aware of negative discourse transfer that may result in ST rhetorical features such as lexical repetition and parallelism being carried over to TT. 


\section{Capitalization}

Aside from signaling proper names, abbreviations or paragraphs, capital letters are used to convey special effects such as emphasis in newspaper headlines and loudness which is usually expressed by extended capitalization. Arabic has no capital 'upper' case letters for initial words, proper names and abbreviations. Instead, round brackets and quote marks are sometimes used not for their normal European function of marking parentheses and quotations, but as a device to overcome the absence of capital letters in Arabic script, particularly with European names that otherwise can be easily confused with common nouns if left unmarked (Beeston 1968:15). For example:

The foreign secretary, Mrs. Clinton, traveled to Tokyo and Jerusalem. سافرت وزيرة الخارجية السيدة كلينتون إلى طوكيو و القدس.

[the foreign secretary mrs. clinton, traveled to tokyo and jerusalem.]

When capital letters are used for emphasis, as in headlines, Arabic uses boldface or a different font colour:

GREAT SATAN SITS DOWN WITH THE AXIS OF EVIL - (The Times on US-Iran talks, 2007). الثنيطان الأكبر يجتمع مع محور الثر

The following warning, frequently found in medicine inserts, is printed in extended capitals:

\section{NOT TO BE DISPENSED WITHOUT PHYSICIAN'S PRESCRIPTION.}

When translated into Arabic the whole clause is underlined (in boldface) to mark the TT for يمنع صرف هذا الدواء بدون وصفة طبية. emphasis

When extended capitals are used in the middle of a text, Arabic employs other punctuation tactics like single quotation marks, parentheses or the insertion of exclamation marks.

You'll need to work her up. Mrs. R. starts to realize Mrs. E-H MAY EVEN HAVE

KNOWN MISERY WAS BURIED ALIVE!! (Stephen King, Misery: 166)

$$
\text { عليك أن تحسن من شكلها.( بدأت السيدة "ر" تدرك أن إيفيلين هايد عرفت أيضا أن "ميزري" دفنت حية.) }
$$

In the following example, notice how the Arabic translation adds the word حقان compensate for the functional loss of emphasis owing to the absence of extended capitalization in Arabic.

"He didn't get out of the cockadoodie car! It went over the edge and he was still inside it! Do you understand that?"

"Yes, " Paul said.

"DO YOU UNDERSTAND THAT?" (Stephen King, Misery: 111)

"لم يخرج من السيارة اللعينة! لقد إجتازت الحافة ولاز ال بداخلها! هل تفهم مأقول؟" "نول"

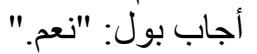

[ل "هل تفهم ذلك حقا؟" [do you really understand that] 
On a similar note, small uppercase capitals may be entered at the same height as surrounding lowercase small letters. Aside from being used instead of italics to indicate emphasis or distinctiveness, they are employed in extended texts to prevent capitalized words from appearing too large on the page. They can also be used to draw attention to the opening of a new text. Some publications use small caps for acronyms and initialisms that consist of more than three letters (e.g. "U.S." and "FDR" in normal caps, but "NATO" in small caps). French publications use small caps to signify the surname by which someone with a long formal name is to be designated in the rest of a written work (e.g. DONQUIXOTE de La Mancha). As pointed out under capitals, Arabic resorts to other means of signifying names, acronyms and initialisms by using parenthesis, quotation marks or boldface letters.

\section{Abbreviations and special symbols}

Titular contractions and abbreviations such as $D r, P M$, and etc as well as acronyms such as $A L P A C$ and $O E D$ are part and parcel of many world Languages. Arabic, however, does not favour original abbreviated forms owing to the fact that such forms require capitalization which is not a feature of Arabic graphology. Therefore, it is common practice that foreign abbreviations are reinstated in their full lexical form while acronyms are transliterated. The following example illustrates that paraphrasing abbreviations will result in an increase in the volume of Arabic translation. For example:

G8 leaders met with NATO members in EU headquarters to discuss the economic crisis. (Total: 14 words).

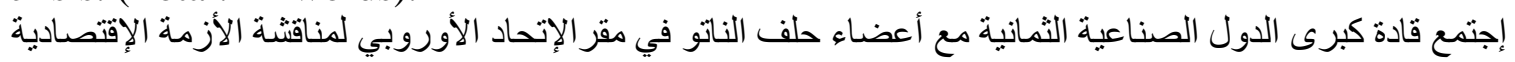

(Total: 17 words +8 prefixed definite articles).

[Leaders of the eight great industrial countries met with NATO pact members at the

European Union headquarters to discuss the economic crisis.]

Another source for the increase in word count is that special ST symbols are normally reproduced in their original characters or, alternatively, reinstated in their full lexical equivalents.

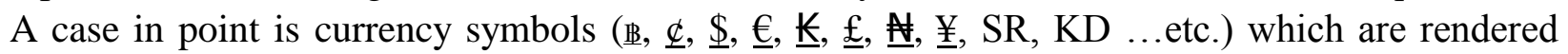
lexically when translated into Arabic. For example:

Your A/C is credited with $\Phi 695$ (i.e. $\underline{€} 500$ ).

تم إيداع 695 دو لار (مايعادل 500 يورو) في حسابك.

Similarly, the ampersand $(\&)$ or $(\varepsilon)$ also commonly called an 'and sign', is a logogram representing the conjunction "and". As there is no graphological Arabic equivalent, the symbol for the ampersand is rendered by the conjunction $g$ [and]:

e.g., Mr. \& Mrs. Dickson.

السيد ديكسون وحرمه or. Dickson and his wife].

When a hash precedes a number, it is read as "number", as in "a \#2 pencil" (spoken as "a number two pencil"). In North America, when it follows a number, it is read as "pounds", as in "5\# of sugar" (spoken as "five pounds of sugar"). The latter is more specifically used in the food service and grocery/produce industries, or other fields where units of pounds (as weight) need to be 
hand-written frequently or repetitively. As with the ampersand, the hash is rendered lexically in Arabic by either the word رقم [ رط [number] or [pound].

\#2 pencil [2 قلم رصاص رقاص

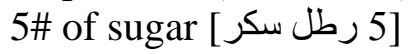

When a period is inserted in the ST to separate numerical digits, a comma is used in Arabic owing to the similarity between the period and the number zero. For example:

$23.456=23.456$

\section{Commas}

The comma is the most frequent punctuation device that occurs in multifarious contexts. This being the case, it exhibits more variations and differences than any other punctuation mark in either English or Arabic.

1. The comma (,) usually separates coordinate sentences, clauses, phrases or items in a series. For example, in a series of three or more items, English uses a comma to separate all but the penultimate and the ultimate item in a list (Newmark 1984: 173). For example:

The Solar system is composed of a star, nine planets and several satellites.

Arabic translates the sentence by dropping the commas and inserting the conjunction $g$ to replace the comma.

يتكون النظام الثمسي من نجم وتسعة كو اكب و عدة أقمار.

[The Solar system is composed of a star and nine planets and several satellites.]

English places commas between adjectives of equal weight, while Arabic uses zero punctuation or an optional $g$.

He immersed his dark soily feet into the blue, clear water of the sea.

[غمس قدميه الداكتتين (و) المتسختين في مياه البحر الزرقاء الصافية.]

2. Transition and commentary words are usually set off with commas. After sentential connectors and transitional words, a comma is used in English; Arabic either reproduces the comma or inserts a lexical substitute. For example:

However, the arbitrator disqualified all audit reports submitted after the deadline. على أية حال، فقد فند المحكم جميع تقارير المدققين التي قدمت بعد الموعد المحدد.

The same sentence can be rendered without a comma by using the lexical equivalent إلإن إن إن إن إن

$$
\text { إلا أن المحكم فند جميع تقارير المدققين التي قدمت بعد الموعد المحدد. }
$$


The above example illustrates that Arabic may resort to lexical substitutes that carry a built-in nonvisual punctuational function that indicates pauses and intonational patterns. Sometimes, the comma is ignored without any substitute.

However, man has always ventured to achieve his dream of flying to the moon.

لكنّ الإنسان كان دائما ما يغامر ليحقق حلمه في الطير ان إلى القمر.

As a result, she intends to apply for a job that suits her credentials.

ونتيجة لذلك فإنها تنوي التقدم لوظيفة تناسب مؤ هلاتها.

When a transition or commentary word occurs in the middle of a sentence, the Arabic translation may reorder the structure. For example:

The jury will, no doubt, pass their verdict before the recess.

بلاشك، سيصدر المحلفون حكمه قبل العطلة.

For matters of coherence, the Arabic translation fronted the transition word followed by a comma. This deliberate reordering is intended to ward off the confusion that may result if بلاشك [no doubt] is misconstrued as a post-nominal modifier for 'the verdict', thus changing the sense to 'a definite verdict'.

3. A comma is added after a subordinate clause: In Arabic, there is subordination as well as coordination, but the latter is more frequently employed than the former. Arabic preference for coordination is not to be considered a drawback or a sign of immaturity in the Arabic discourse. Coordination is the main key for coherence in Arabic, just like subordination in English (Othman 2004: 23). Some Arabic texts translated from English often tend to exhibit an unusually considerable presence of subordination, which is not in line with Arabic fondness for coordination (Othman 2004: 21). The result is an unavoidable unnaturalness ascribed to the influence of the ST. Therefore, a translation that would sound natural in Arabic would entail a higher frequency of coordination than of subordination. The following English text implements commas and other punctuation marks to produce elaborate subordinate structures while its Arabic translation employs coordinate conjunctions that offset many of the ST punctuation devices.

One major solution to the problems of large-scale organizations has been the development of bureaucracy, which Robert K. Merton defines as "a formal, rationally organized social structure [involving] clearly defined social patterns of activity in which, ideally, every series of actions is functionally related to the purposes of the organization." This sociological definition, which we shall follow, contrasts sharply with the widespread use of "bureaucracy" and 'bureaucrat" as political epithets often applied to governmental agencies and officials, for whom the conventional stereotype is the officious, rule conscious, responsibility dodging clerk entangled in red tape and preoccupied with busy-work.

(Translators' Qualifying Exam 1998, ITI, London)

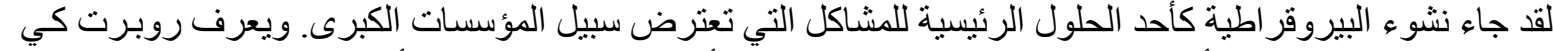

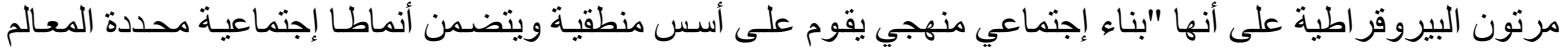

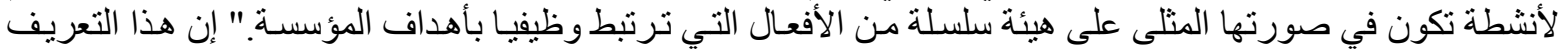




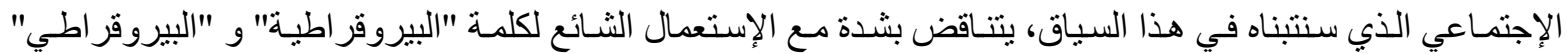

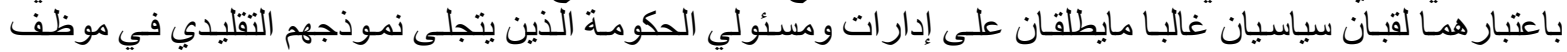
المكاتب المتغطرس الذي يتمترس بالقو انين ويتحاثنى المسئولية ويغوص في أعماق الروتين ويتوه في مشاغل العمل.

(Award Winning translation by the author of the present paper)

Statistically, the English original uses nine commas, two periods and three coordinate conjunctions while the Arabic translation has only one comma, three periods and seven coordinate conjunctions.

When a comma is used in English to separate a fronted subordinate clause from the main sentence, Arabic tends to delete the comma with no substitute.

Although casualty estimates vary, it is widely accepted the sudden outbreak of swine flu had damaging effects on global economy.

$$
\begin{aligned}
& \text { بالرغم من تفاوت التقدير ات حول عدد الضحايا فإنه من المتعارف عليه و على نطاق و اسع أن الإنتشار }
\end{aligned}
$$

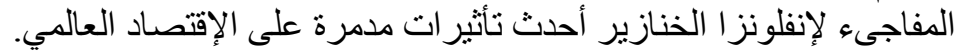

According to UNESCO figures, illiteracy is still rampant in Africa. وفقا لإحصائيات اليونسكو فإن الأمية ماز الت متفنشية في أفريقيا.

In the following example, Johnstone (1991: 89-90) provides a literal translation of the following Arabic paragraph.

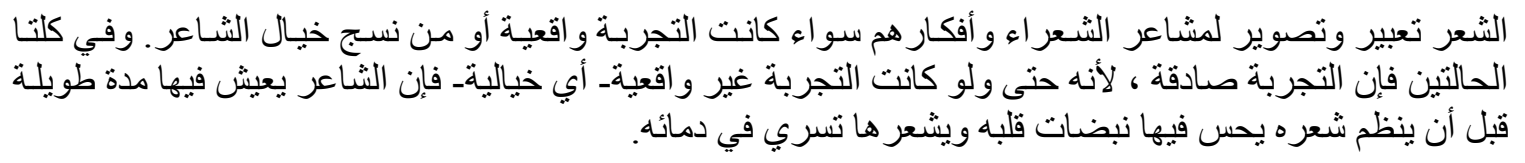

Poetry is an expression and description of the feelings of poets and their thoughts, whether the experience be real or from the fabric of the poet's imagination. And in both cases, the experience is true, because even if the experience is not real- that is, imaginary- the poet lives in it for a long time before he composes his poetry, sensing it in the pulses of his heart and feeling it flow in his blood (Johnstone 1991: 89-90).

Unlike the Arabic ST, the English translation enters a comma before the two subordinate clauses 'whether the experience...' and 'And in both cases'.

Sometimes a comma after a subordinate clause indicates a sudden occurrence:

As the train approached the intersection, a truck rammed into the middle of its track.

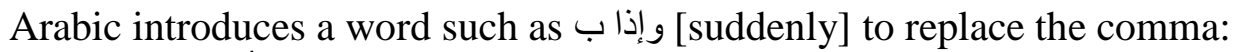

وحينما إقترب القطار من التقاطع و إذا بشاحنة تتوقف (فجأة) في وسط السكة.

4. When a non-defining clause begins with an -ing verb, it is usually set off with a comma (Robbins 1988: 14). 
"The company will be overtaken by Super Electronics," said the chairman, addressing the general assembly.

قال رئيس مجلس الإدارة و هو يلقي كلمته أمام الجمعية العمومية: ستستحوذ "سوبر إلبكترونيكس"على شركتنا.

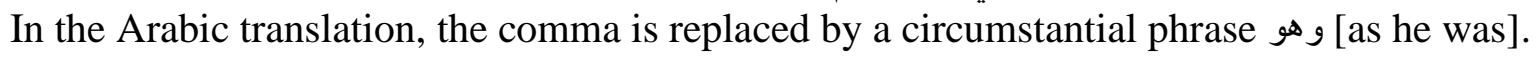

5. English uses a comma after an attribution that precedes simple quotations, e.g., The CEO said, "Welcome aboard!" In translation, Arabic usually uses a colon instead.

قال المدير : "مرحبا بانضمامكم للشركة!"

When an attribution occurs in the middle of a sentence, the attribution is surrounded by a set of commas in English. Arabic fronts the attribution and joins the two parts of the quotation into a single sentence.

More than 180,000 homes and businesses were without power Thursday night, said Megan Wright, a spokeswoman for Oncor Electric Delivery. (Associated Press, June 12, 2009)

قـال ميجـان ر ايـت المتحدث بإسـم شـركة أونكور إليكتريك ديليفري بـأن الكهربـاء إنقطعت عن أكثر من 180

[Megan Wright the spokesman for Oncor Electric Delivery Company said that power was down for more than 180,000 homes and businesses Thursday night.]

6. English inserts a comma to separate the two parts of an antithetical statement where the second part of the sentence contradicts the first; Arabic inserts an optional comma. For example:

I sent a letter, but I did not get a reply.

أرسلت رسالة (، لكني لم أنلق ردا.

It should be noted that in the presence of a conjunction like و [and] or إلا أن/ غير/ لكن [but, yet, however], the comma becomes dispensable.

7. Another optional comma in Arabic is inserted after a fronted conditional clause, albeit the sentence is perfectly acceptable with no comma at all.

] لو كنت نائبا في المجلس (،) لاستقلت. [If I were a council member, I would resign.]

\section{Parenthetical clauses and sentences:}

Commas are inserted to set off nonrestrictive or non-defining appositives (phrases that describe or explain a given word in the sentence and share its grammatical function). English uses a set of commas to surround additional or parenthetical descriptive phrases which may interrupt the subject-predicate sequence. Arabic favours reordering sentences and introducing linking words to offset the lack of parenthetical commas, for example:

The institute, which was founded by Stuart Martin, offers graduate studies in biophysics and geology. 
The above sentence may be rendered in Arabic in two different manners. It may be translated without the commas with the addition of a relative clause as in:

$$
\text { إن المعهد الذي أسسه ستو ارت مارتن يقدم در اسات عليا في الفيزياء الحيوية و الجيولوجيا. }
$$

It may also be reordered by moving the parenthetical phrase to a terminal position preceded by a linking word such as علما [bearing in mind].

$$
\text { يقدم المعهد در اسات عليا في الفيزياء الحيوية و الجيولوجيا علما بأننه تأسس على يد ستو ارت مارنن. }
$$

[The institute offers graduate studies in biophysics and geology bearing in mind that it was founded by Stuart Martin.]

In the next sentence, the comma is replaced by the pronoun وهي [which is].

No one came to the lecture but five students from Lincoln College, a technical institute in New Jersey.

$$
\text { لم يحضر المحاضرة سوى خمسة طلاب من كلية لنكولن و هي معهد يقع في نيوجيرسي. }
$$

[No one came to the lecture but five students from Lincoln College which is a technical institute located in New Jersey.]

The long parenthetical structure in the following example is resolved in Arabic by deleting the commas and fronting the parenthetical sentence to an initial position.

OPEC members, after enjoying record revenues as a result of the drastic increase in oil prices in 2008, suffered a massive deficit as oil prices plunged in the aftermath of the credit crunch in 2009.

$$
\begin{aligned}
& \text { بعد العائدات القياسية التي حققتها إثر الإرتفاع القياسي في أسعار البترول في } 2008 \text { عانت دول الأوبك }
\end{aligned}
$$

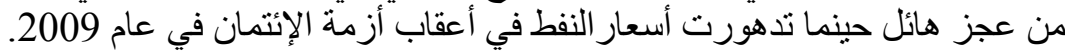

[After enjoying record revenues as a result of the drastic increase in oil prices in 2008 OPEC members suffered a massive deficit as oil prices plunged in the aftermath of the credit crunch in 2009.]

9. Sometimes, when a comma substitutes a relative pronoun in English, the Arabic translation deletes the comma and reinstates the pronoun or another equivalent.

In the steppes, north Russia, rivers flow from the south to the north where they freeze and create a backlog of floods.

$$
\text { في مناطق الستبس (بشمال/ التي تقع/الواقعة) في شمال روسيا تجري الأنهار من الجنوب إلى الشمال حيث تتجمد }
$$

[In the steppes which is situated in north Russia rivers flow from the south to the north where they freeze and create a backlog of floods.]

10. A comma is used to introduce direct questions.

The issue is, who will pay for the damages?

Arabic may either delete the comma or insert a colon: 
المشكلة هي: من سيدفع قيمة الأضرار؟ or المشكلة هي من سيدفع قيمة الأضرار؟

11. A comma is inserted after a direct address.

Mr. Richard, could you attend the meeting on behalf of the chairman?

Arabic either uses a comma or a colon.

ياسيد ريتشارد، هلا حضرت الإجتماع نيابة عن رئيس مجلس الإدارة؟

ياسيد ريتشارد: هلا حضرد هلات الإجتماع نيابة عن رئيس مجلس عنس الإدارة؟

12. Commas are used with dates that include day and year.

September18th, 2010, is the first day of the conference.

Arabic either ignores the comma or inserts slant lines.

أول يوم للمؤتمر سيكون بتاريخ 18 سبتمبر 2010 (2010/9/18)

\section{Semicolons}

The semicolon (;) has medium pause duration between that of a comma and a period. It identifies the coordinate parts of a complex sentence or is used to separate independent but related clauses in a list that are not joined by a conjunction. It is also used with a series that has internal commas or that might be confusing when only commas are used.

Offerings for breakfast include waffles, juice, and coffee; eggs or eggs with sausage, with or without potatoes, juice, and tea; omelets with a choice of fillings, tea or coffee; or simply juice, coffee, and toast (Robbins: 20).

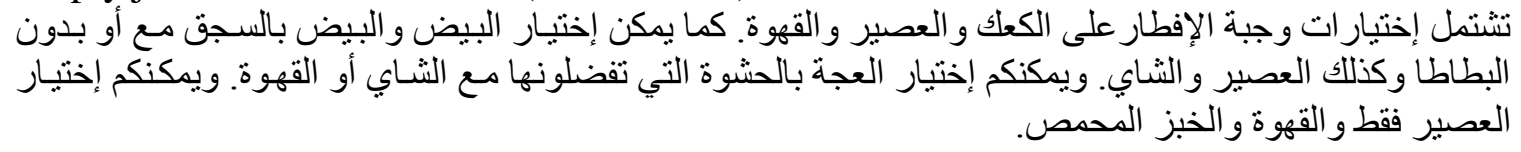

The English ST uses semicolons to set off separate combo choices for breakfast offerings. The punctuation is intended to defuse any confusion that may be caused by using commas only. The Arabic translation uses periods as a substitute but also repeats the word إختيار [offering/choice] at the beginning of each sentence in order to signal each combo as a package.

A semicolon is also used between two parallel sentences bearing similarity or contrast (Newmark 1984: 175). For example:

Man proposes; God disposes.

العبد في التفكير و الرب في التدبير.

The Arabic translation substituted the semicolon with a coordinate conjunction $و$ [and].

In the following excerpt, the semicolons have been replaced by the conjunction 9 [and].

If that documentation was prepared outside your own organization, do you have a reliable system in place to insure that you receive copies of the information as 
submitted to Customs; that it is reviewed for accuracy; and that Customs is timely apprised of any needed corrections?

(U.S. Customs, Voluntary Compliance Systems, Training Course 2008)

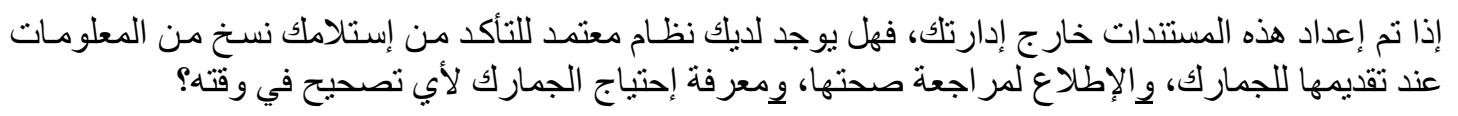

The process may be reversed when translating from Arabic into English. A linking word such as or even a prefix such as ف can be replaced by a semicolon in English.

أثرت السياسات الإقتصـادية في مناهج التعليم فالتوجه النفعي أهمل الأدب الإبداعي و العلوم الإنسانية.

Economic policies have influenced educational curricula; the pragmatic approach ignored creative literature and humanities.

Dickins et al. (2005: 26) translates an excerpt from the Arabic London-based magazine al-Aalam العـالم. Although the original consists of one (run-on) sentence, the translation introduces semicolons and commas in order to conform to TT punctuation norms.

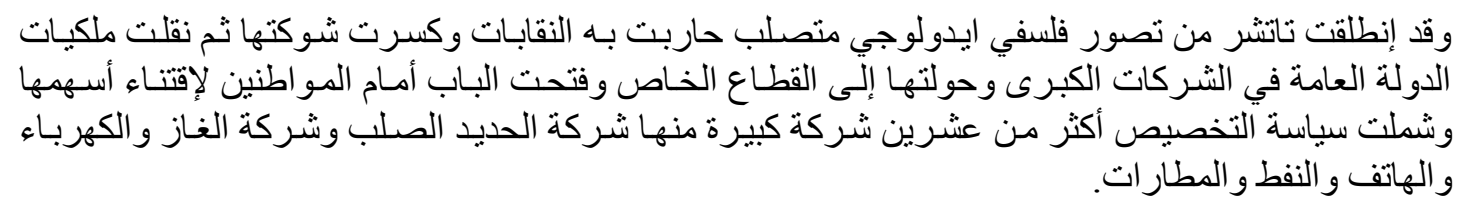

Thatcher set off from an unyielding philosophical-ideological conception with which she fought the unions and broke their power; then she transferred the public properties of the state in the great companies and converted them to the private sector, and opened the door in front of citizens to buy their shares; and the policy of privatization covered more than twenty large companies, including the iron-steel company, the gas company, the electricity, the telephone, the oil, and the airports.

Sometimes a semicolon is introduced before a phrase/sentence that elaborates or concludes a preceding main sentence.

The GCC countries agreed on the introduction of a common currency; a procedure that will promote financial exchange, consolidate inter-market activities and create a stronger negotiation front; boosting their capacity to compete globally.

Since there is no Arabic equivalent for the use of the semicolon in such a context, the translated version of the sentence adds a phrase such as في إلأمر الذي يؤدي إلى [within the framework] and or مما يؤدي إلى [a matter that, resulting in].

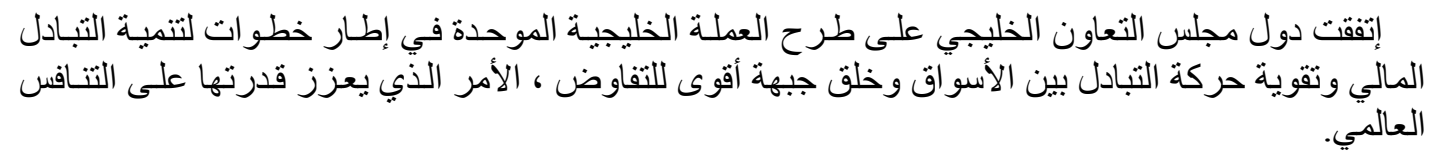

[The Gulf Cooperation Council countries agreed on the introduction of a common currency within the framework of procedures to promote financial exchange, consolidate inter-market activities and create a stronger negotiation front, a matter that boosts their capacity to compete globally.] 


\section{Colons}

The colon (:) often introduces an explanation or series of examples usually in a list of entry fields e.g. "Name: ". As with the semicolon, a colon may be inserted before a sentence which elaborates a preceding one. The 'topic' clause or sentence frequently includes a word such as 'the following', 'there are', 'means' or an expression of quantity while the 'complement' provides comment on the preceding topic (Newmark 1984: 174).

Luckily, the Supreme Court gave its ruling just in time: the candidate is acquitted and he can run for the mayor's election.

In translation the colon may either be retained or replaced by a semantically equivalent phrase [ حيث نص على [that is/which is] or it stipulated]:

$$
\text { و ولحكنه من التقدم لإنتخابات أصدرت العمدة. العكليا حكمها في الوقت المناسب ألا وهو (حيث نص على) تبرئة المرشح }
$$

[Luckily, the Supreme Court gave its timely ruling which (is) / (stipulated) that the candidate is acquitted and that he can run for the mayor's election.]

قررت . Another alternative would be the use of a verb synonymous with ruling (e.g 'decided':

$$
\text { ولتقدن الإنتخابات العمدة. أصدرت المحكمة العليا حكمها في الوقت المناسب حيث قررت تبرئة المرشح وتمكنه من }
$$

[Luckily, the Supreme Court gave its ruling just in time: it decided that the candidate is acquitted and that he can run for the mayor's election.]

\section{8. $\underline{\text { Hyphens }}$}

A hyphen is used to separate compound words (e.g. two-pronged forklifts vs. two pronged-forklifts). Upon translating hyphenated compounds into Arabic, the hyphen is often ignored or is replaced by substitute words. For example:

The iron-steel company شركة الحديد الصلب

The London-based newspaper الصحيفة التي تتخذ لندن مقر الها/ الصحيفة التي تنشر في لندكة (the hyphen has been replaced by a relative clause التي فن فن فن 'which is')

Deep-rooted customs تقاليد متأصلة (the compound adjective has been replaced by a single word).

Mother-daughter relationship علاقة الأم بإبنتها (the hyphen has been replaced by a preposition $\varphi)$. 


\section{Dashes}

A dash (-) is used for a stronger separation than commas provide. It is sometimes used singly to separate a comment or afterthought at sentence end. When in the middle of a sentence, it is used in pairs to indicate a sudden shift in thought, hesitation or to separate parenthetical material or replace such expressions as that is and namely. Writers use dashes sparingly since they tend to interrupt the flow of a sentence conspicuously (Newmark 1984: 174).

1. In the following example, a dash is inserted before a comment at sentence end.

We will sell the car in Colorado - if it ever gets us there!

سنبيع السيارة في كولور 1دو هذا إن أوصلتنا إلى هنالك !

Instead of reproducing the dash, the Arabic sentence prefers to reinstate the lexical equivalent of that is هذا

2. A dash may also be used to precede an explanation or a specific statement of purpose:

Janet sold her house for one reason — she was in debt.

The Arabic translation substitutes a lexical equivalent ألا وهو [namely/that is] for the dash.

باعت جانيت منزلها لسبب واحد ألا وهو أنها كانت مدينة.

3. A dash may also be inserted to indicate surprise and suddenness:

The tourist paid a fortune anticipating a five star hotel, but found $\square$ a shabby wooden cottage.

The Arabic translation substitutes the dash with a word that expresses the meaning of surprise and shock لد هشتنه:

$$
\text { كوفع السائح مبلغا طائلا وكان يتوقع أن يكون الفندق بدرجة خمسة نجوم ولكن لاهشته (فوجىء) بأنه لم يكن سوى }
$$

4. In the following sentence, English inserts a dash before a final conditional clause; Arabic may either use a comma or zero punctuation.

She will buy a chalet in Hawaii-if she wins the lottery.

$$
\text { لو ربحت اليانصيب (،) ستشتري شاليها في هاو اي. }
$$

5. A dash may be used to indicate an unfinished thought.

"But when—?" he retorted.

Arabic uses ellipses: " أجاب بحنق: "ولكن منى...

6. In the following example, Arabic prefers to reinstate the lexical equivalent بالتحديد [namely] instead of the pair of dashes. 
The customs officer found many narcotic bags — thirteen — stashed away in the dashboard.

$$
\text { وجد موظف الجمارك العديد من أكياس المخدر ات وبالتحديد ثلاثة عشر كيسا مخبأة في لوحة مفاتيح السيارة. }
$$

7. A pair of dashes is sometimes used instead of commas to separate a long comment or interpolation.

This contraption - as Adam likes to call it-will work efficiently in humid climates.

$$
\text { إن هذا الجهاز - كما يحلو لآدم أن يسميه- يعمل بفعالية في المناخ الرطب. }
$$

As can be observed from the translation, the Arabic dash has the size of a hyphen. Arabic may also use parentheses or commas to do the same function.

My grandfather — may God bless his soul—used to fast every Monday. كان من عادة جدي (رحمة الله عليه) أن يصوم كل إثنين.

It is also possible to render the above sentence without dashes or parentheses since the parenthetical phrase may be considered an inseparable post-nominal attribute of the subject.

كان من عادة جدي رحمة الله عليه أن يصوم كل إثنين.

8. A dash is used to set off a series that requires commas in the middle of a sentence (Robbins: 10). For example:

The instructor listed the tasks — scrubbing, polishing, puffing, washing — that are required before a paint job is delivered.

سرد المدرب المهام المطلوبة قبل تسليم أعمال الصبغ كالدعك، و التلميع،و النفث, و الغسيل.

As can be seen in the translation, Arabic prefers to create a more coherent structure by deleting the dash and moving the listed items to the end of the sentence.

\section{Quotation marks and guillemets}

Single (' ') or double quotation marks (" ") set off either citations, quoted speech, neologisms, words used with special significance or unusual sense, or words used ironically. When a word or phrase is put in inverted commas, it can be translated literally or transliterated if TL has no equivalent, since the translator is relieved of the responsibility of its authenticity (Newmark 1984: 172). For example:

Al-Jazeera quoted the Defense Minister as saying, "We have two regiments in southern Iraq"; the Minister denied saying that number, claiming there are only border security guards.

$$
\text { أنه لايوجد الجزيرة عن وزير الدفاع قوله: "لدينا فوجين في جنوب العراق"، إلا أن الوزير نفى ذكره مثل هذا الرقم وأعلن }
$$

The Palm Tree project has been described as Dubai's "jewel of the crown".

$$
\text { وصف مشروع النخلة بأنه "جو هرة التاج" لدبي. }
$$


Aside from the conventional quotation marks, traditional Arabic texts use guillemets (( ${ }^{)}$,parentheses ( ) or zero marks for quotations. This may be justified by the likelihood of mistaking English quotation marks for the superscript Arabic diacritics namely the double dammah " used for the nunnation of the subjective nominal case. Guillements are used to distinguish proper names from other common nouns and to signify special meanings. For example:

في المبار اة النهائية فاز ((الوحدة )) على ( النصر ) ) بهدفين مقابل لاشيء.

In the final game, al-Wihdah defeated al-Nasir 2-nil.

It can be noted that the English translation discarded the guillements by using capital initials for the proper names.

Dickens et al. (2005: 45) quotes the following line from a dialogue taken from the opening

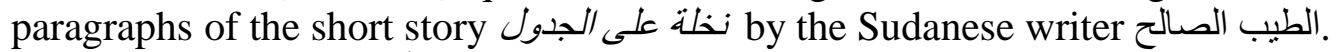

$$
\text { (الضحية. )) جنيها يار جل ، تحل منها ماعليك من دين ، وتصلح بها حالك. وغدا العيد وأنت لم تثنتر بعد كبش }
$$

This has been translated by Montgomery (1994: 21) with single quotation marks.

'Look here my man, with twenty pounds you could settle your debts and make your life a lot easier. The Eid festival is tomorrow and you haven't even bought a sacrificial lamb yet.'

In some instances, quotation marks are ignored in Arabic dialogues as in the following excerpt from the short story الأرجوحة by Mohammad Khudair (adapted from Aziz et al. 1985: 234).

- Your son is in the army, ma'am, isn't he?
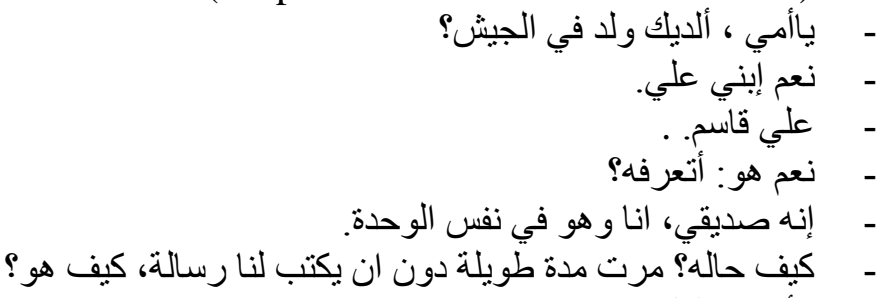

- Yes my son Ali.

- Ali Qasim.

- Yes it is him; do you know him?

- He is my friend; we are in the same unit.

- How is he? It has been a while since he wrote to us, how is he?

- Ma'am, your son is...

\section{The apostrophe}

(') marks the possessive case or the omission of letters. The symbol of the apostrophe is similar to the superscript diacritic of the 'damma' ( $\left.{ }^{\prime}\right)$ in Arabic which is used for the inflectional 
ending of nouns in the subjective case. However, since Arabic punctuation lacks the possessive apostrophe, it is often replaced by the genitive case.

The hail damaged Jane's garden.

أتلف البرد حديقة "جين".

The apostrophe is also used in English to signal grammatical contractions (e.g. I'll, he's, we won't). Since Arabic has no equivalent use for the apostrophe in such contexts, translations of English grammatical contractions restore the full words in the TT, for example,

I'll attend the meeting even though I'm certain he won't show up.

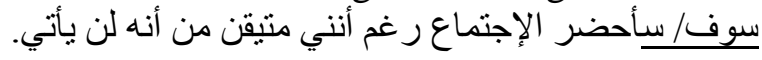

\section{Italics}

Italics can be ambiguous as they may be used variously to highlight foreign words, technical terms, published titles, emphasis, and several other functions. However, they are rarely used in original Arabic writings as writers often prefer to use parentheses, underlining or single quotation marks for the same purpose. Indeed, a close look at the font forms available for most computer software would reveal that the form of Arabic italics is simply adopted from Latin font forms since Arabic italics are slanted in a left to right direction instead of the usual right to left.

Names and titles of publications are italicized in English while in Arabic the tendency is to use parentheses, boldface or underlining, e.g., The Herald Tribune (الهير الد نربيون) boldface:

A published bibliographic entry may either use italics or underlining with or without

Baalbaki, R. 1998. Al-Mawrid: A Modern Arabic-English Dictionary. Beirut: Dar El-Ilm Lilmalayin.

بعلبكي، ر. 1998. المورد: قاموس عربى إنجليزي. بيروت: دار العلم للملايين.

Intertextual italics are used to highlight dialogues or to mark emphasis or words with special meaning. Arabic does not normally use such a technique and in translating italicized words and sentences, quotation marks or parentheses are inserted. However, in view of the joint case of Arabic orthography, variations in emphasis may be inevitable in translation. In the following excerpt, italics are used to highlight the pronoun without the preceding verb. But since Arabic suffixes the pronoun to the verb, both receive emphasis in the translation. In order to retain the orthographical effect of the ST, a separate second person pronoun أنت may be inserted in parentheses.

"Well, I ... all right. I ...thank you."

"I should be thanking you. May I see that paper?" (Stephen King, Misery: 157)

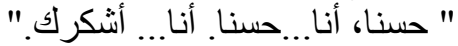

" أنا الذي يجب أن أنشكرك ( أنت). أنسمح لي برؤية الورقة؟ " 


\section{Letter repetition and spacing}

Repeated letters (with or without hyphens) indicate emphasis or especially prolonged articulation. While Arabic uses this technique particularly in folktales, cartoon and caricature captions, internet chats, blogs and twitters, letter repetition is sometimes supplemented by additional words or other punctuation marks. For example:

'Shhhhhhhhhhh! Shhhhhhhhhhhhhh!' they said. (William Faulkner, Dry September- in Crystal 1988: 181).

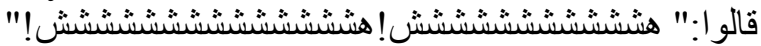

Alternatively, the classical word صـ [be quiet] may be used with extra type space.

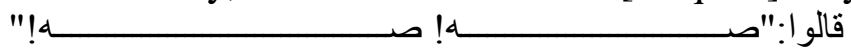

In the following example, three colloquial words are written with repeated letters:

ليييش ليييش؟؟؟ لعبة حلووووة!!!! ومروووور ج بكبره أحلى!!!

(http://www.a3zk.com/vb/archive/index.php/t-1243.html)

[Whyyy, whyyy??? A beautiful game!!! And your looog in is even more beautiful!!!].

And I've lost you, lost myself,

Lost all-1-1-1-

(Robert Browning, Men and Women- in Crystal 1988: 181)

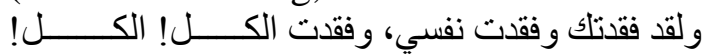

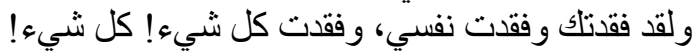

كل شيء Instead of repetition, the second Arabic translation renders 'all-1-1-1-' in two words [everything] for more emphasis.

\section{Conclusion}

While variations in punctuation are a natural consequence of translation, deviations become even more evident between languages of different families and cultures such as English and Arabic. Punctuation marks that were transferred into Arabic from European languages through translation such as the comma, quotation marks and parentheses have been utilized with multiple and sometimes overlapping functions. Other marks such as the semicolon are rare while the apostrophe is not used at all. Arabic does not solely rely on conventional punctuation as a marker of sentence division and even in those texts that do, punctuation is not always a clear guide. Intersentential conjunctions, discourse markers, superscript diacritics and lexical insertions create coherence without the need for visual space division.

It should be noted that some examples that were collected in our investigation were discarded since they were not representative of 'standard' Arabic punctuation. Some writers produce texts with special orthographical effects as part of their stylistic imprint. In such cases, a translator is required to reproduce ST anomalies even if the TL lacks their equivalents.

In the course of conducting our research, we have noticed that this field of study lacks adequate investigation of other pairs of languages. Some areas that invite more contrastive 
analysis concern writing formats of specific genres such as, advertising, subtitling and campaign literature, to name but a few.

\section{References}

Aziz, Yusuf et al. 1985. Translation: Scientific, Journalistic and Literary. Baghdad: Al-Mosul University Press.

Beeston, Alfred F.L. 1968. Written Arabic: An approach to the Basic Structures. Cambridge: Cambridge University Press.

Catford, John. 1965. A Linguistc Theory of Translation. London: Oxford University Press.

Chejne, Anwar. 1969. The Arabic Language, Minneapolis: University of Minnesota Press.

Crystal, David. 1988. The Cambridge Encyclopedia of Language. New York: Cambridge University Press.

Dickins, James; S. Hervey; I. Higgins. 2005. Thinking Arabic Translation, London and New York: Routledge.

Hatim, Basil. 1990. The Status of the Paragraph in Translation. Nouvelles de la FIT IX, 1990 (12):120-130.

Johnstone, Barbara. 1991. Repetition in Arabic: Paradigms, Syntagms and the Ecology of language. Amsterdam: John Benjamins.

Longacre, Robert E. 1979. The Paragraph as a Grammatical Unit. In T. Givon (ed.), Syntax and Semantics, Vol. 12, 115-133. New York: Academic Press.

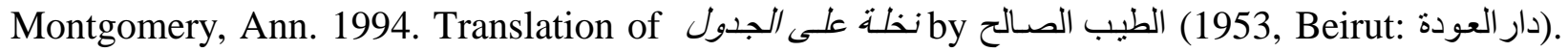
BA translation project: University of Durham.

Newmark, Peter. 1984. Approaches to Translation. Oxford: Pergamon Press.

Othman, Waleed. 2004. Subordination and Coordination in English-Arabic Translation. AlBasaer, 8 (2): 12 - 33.

Robbins, Sam. 1988. Editing, Period Styles: A History of Punctuation: An Exhibit at the Cooper Union, March 22-April 22, 1988. New York University.

The Noble Qur'an: Translations of the Meanings of the Noble Qur'an, Madinah, Saudi Arabia: King Fahad Complex for the Printing of the Holy Qur'an, 1420 A.H. 